\title{
Cytogenetics and Biology of the Intermediate Host of Human Bilharziasis, Bulinus truncatus Common in Upper Egypt
}

\author{
Ahmed E. Yaseen \\ Zoology Department, Faculty of Science (QENA), Assiut University, Egypt
}

Accepted November 13, 1992

The African freshwater genus Bulinus is the subject of intensive study because some species serve as intermediate hosts in the transmission of human and bovine schistosomiasis, also they have potential significance as a model system for the study of polyploidy in animals and there appears to be some association between ploidy level and ability to transmit the parasite (Wright 1971, Burch 1967, Browin 1978). Bulinus truncatus is one of the very important and widespread species in Egypt. It belongs to Family Planorbidae, Order Basommatophra, Subclass Pulmonata. According to Wright (1963) Burch (1972) and Jawetz et al. (1987) the genus Bulinus possesses a sinistral shell and a pseudobranch. It breathes by a pulmonary sac and its shell lacks an operculum. This species is hermaphordite. The nervous system is composed of two pleural, two parietal and one abdominal ganglia.

The basic chromosome number $(\mathrm{X})$ of this genus is the same as that of its family, the planorbidae, i.e. $X=18$. Previous work has suggested that a haploid chromosome number of $n=$ 18 is characteristic of the tropicus, africanus and, froskali species groups and $\mathrm{n}=36$ (or higher multiples) is characteristic of the truncatus species group (Table 2, Goldman et al. 1984).

Burch (1964) and Nataragen et al. (1965) have reported 35 samples of Bulinus from several central African countries of the Mediterranean area, from Asia Minor and from Western Aden Protectorate and found that the species of tropicus and truncatus groups investigated possessed haploid sets of 18 and 36 chromosomes, respectively. They also found a polyploid series including diploid $(n=18)$, tetraploid $(n=36)$, hexaploid $(n=54)$ and, octaploid $(n=72)$ in natural populations in Ethiopia.

Since polyploidy occurs in this genus, a comparison of the chromosome numbers of the various species brings to light some of still unresolved problems of systematics of the Planorbid subfamily Bulininae.

In the present paper, we have undertaken a study of chromosome numbers and standard karyotype of Bulinus truncatus species and to clarify the polyploidy level of this species.

\section{Materials and methods}

Snail stocks for this study were maintained in shallow plant trays with aerated water and were fed lettuce and supplement containing wheat germ and tetra-Min fish food (Burce and Rodke 1971).

About fifty individuals were used in the morphological analysis of shell parameters. Four shell dimentions shown in Fig, 1: Height $(\mathrm{H})$, Width (W), Aperture Lenght (AL) and Aperture Width (AW), were measured for each snail using a dial caliper and a calibrated eyepiece. Spire length (L/AL), shell shape (L/W) and aperture shape (AL/AW) were calculated according to James (1968) in order to eliminate discrepancies resulting from size differences between individual samples. The recommended terms used by James (1968) and Gregoire (1972) to describe the latter three shell parameters are necessary to species as shown in Table 1. 
with watchmaker forceps pipetted through two changes of aerated well water. The embryos were then placed in shallow dish with a minimum of water flooded with $0.125 \%$ colchicine in well water and incubated $30 \mathrm{~min}$ at room temperature. The colchicine was removed, the

Table 1. Showing the appoved description and ranges of shell, spire and, aperture shapes

\begin{tabular}{|c|c|c|c|c|c|}
\hline \multicolumn{2}{|c|}{ Shell shape } & \multicolumn{2}{|c|}{ Spire shape } & \multicolumn{2}{|c|}{ Aperture shape } \\
\hline \multicolumn{2}{|c|}{ Length/width } & \multicolumn{2}{|c|}{$\begin{array}{l}\text { Length/Aperture } \\
\text { length }\end{array}$} & \multicolumn{2}{|c|}{$\begin{array}{c}\text { Aperture/Aperture } \\
\text { length }\end{array}$} \\
\hline $\begin{array}{l}\text { Broader than } \\
\text { long }\end{array}$ & $\begin{array}{l}\text { Less than } \\
\quad 1.0\end{array}$ & Very short & $\begin{array}{l}\text { less than } \\
1.35\end{array}$ & Very wide & $\begin{array}{l}\text { Less than } \\
\quad 1.30\end{array}$ \\
\hline Very broad & $1.0-1.10$ & Short & $1.35-1.50$ & Wide & $1.30-1.40$ \\
\hline Broad & $1.10-1.20$ & Medium & $1.50-1.65$ & Fairly wide & $1.40-1.50$ \\
\hline Fairly broad & $1.20-1.30$ & Tall & $1.65-1.80$ & Narrow & $1.50-1.60$ \\
\hline Narrow & $1.30-1.40$ & Very tall & $\begin{array}{l}\text { More than } \\
1.80\end{array}$ & Very narrow & $\begin{array}{l}\text { More than } \\
\quad 1.60\end{array}$ \\
\hline Very narrow & $\begin{array}{l}\text { More than } \\
1.40\end{array}$ & & & & \\
\hline
\end{tabular}

Table 2. Previously published chromosome numbers of Bulinus (Planorbidae-Gastropoda)

\begin{tabular}{|c|c|c|c|c|}
\hline Species & \multicolumn{2}{|c|}{$\begin{array}{l}\text { Chromosome } \\
\text { number }\end{array}$} & Source & Reference \\
\hline \multicolumn{5}{|l|}{ Africanus group } \\
\hline B. africanus ovoideus & 36 & 18 & Tanzania & Burch 1967a \\
\hline B. globosus & 36 & 18 & $\begin{array}{l}\text { Liberia, Ghana, Zambia } \\
\text { Rhodesia, S. Africa }\end{array}$ & Natarajan et al. 1965 \\
\hline B. nasutus nasutus & 36 & 18 & Tanzania & Burch 1967a \\
\hline B. nasutus productus & 36 & 18 & Tanzania & Burch 1967a \\
\hline B. jousseaumei & 36 & 18 & Senegal & Natarajan et al. 1965 \\
\hline B. ugandqe & 36 & 18 & Tanazania & Burch 1967a \\
\hline \multicolumn{5}{|l|}{ Forskalii group } \\
\hline B. becarii & 36 & 18 & W. Aden & Natarajan et al. 1965 \\
\hline \multirow[t]{2}{*}{ B. forskalii } & 36 & 18 & $\begin{array}{l}\text { W. Aden, Ghana, } \\
\text { Tanzania, S. Africa }\end{array}$ & Natarajan et al. 1965 \\
\hline & 38 & 19 & Angola & Natarajan et al. 1965 \\
\hline B. reticulatus & 36 & 18 & W. Aden & Natarajan et al. 1965 \\
\hline B. senegalensis & 36 & 18 & Senegal & Natarajan et al. 1965 \\
\hline \multicolumn{5}{|l|}{ Tropieus group } \\
\hline B. guernei & 36 & 18 & Senergal & Natarajan et al. 1965 \\
\hline B. natalensis & $36-42$ & $18-21$ & Rhodesia, S. Africa & Burch 1964 \\
\hline B. tropicus tropicus & 36 & 18 & $\begin{array}{l}\text { Kenya, Rhodesia, } \\
\text { S. Africa }\end{array}$ & Burch 1964 \\
\hline B.t. angolensis & 36 & 18 & Zambia & Burch 1964 \\
\hline B.t. zanzebaricus & 36 & 18 & Tanzania & Burch 1964 \\
\hline B. $s p$ & 36 & 18 & Ethiopia & Burch 1964 \\
\hline \multicolumn{5}{|l|}{ Truncatus group } \\
\hline B. coulboisi & 72 & 36 & Tanzania & Burch 1964 \\
\hline B. schackoi & 72 & 36 & Ethiopia & Burch 1967 \\
\hline B. truncatus truncatus & 72 & 36 & $\begin{array}{l}\text { Sardinia, Iran, Iraq } \\
\text { Egypt, Sudan }\end{array}$ & Burch 1964 \\
\hline B. truncatus rohlfsi & 72 & 36 & Ghana & Burch 1964 \\
\hline B. $s p$ & 72 & 36 & Ethiopia, W. Aden & Burch 1964, 1967 \\
\hline B. $s p$ & 108 & 54 & Ethiopia & Burch 1967 \\
\hline B. sp. & 144 & 72 & Ethiopia & Burch 1964 \\
\hline
\end{tabular}


embryo was washed through one change of $0.45 \%$ potassium chloride for 30 min, potassium chloride was replaced with fresh fixative ( 3 parts methanol: one part acetic acid). Small pieces of tissues were transferred to $60 \%$ glacial acetic acid solution and allowed few minutes before shaking vigorously to achieve disorganization into cell suspention. The cell suspention was dropped onto slides which were warmed to $40^{\circ} \mathrm{C}$ and dried in air. Finally slides were stained in $5 \%$ Giemsa.

Suitable metaphase plates were photographed. Measurements and calculations were made and chromosome lengths were standardized as a percent of total complement length (Paris Conference 1971). Centromere position is described according to criteria established by Levan et al. (1964).

Different organs, i.e. gills and gonads were treated by the previous technique which described by Babrakzai et al. (1976) but did not give good results like embryo tissues.

\section{Results and discussion}

Habitat: Bulinus truncatus is one of the most common members of the freshwater snail fauna in Upper Egypt, found most frequently along the margins and banks of small ponds, slow running or almost stagnat irrigation canals. This snail is also found among aquatic vegetation or clinging to any holdfast, such as, pieces of palmfronds, driftwood, timber and, stones. In nature this is found in common association with other genera: biomphalaria, Lanistes, physa and Bellamya. This species is found in fairly good numbers throughout the entire months of the year, yet it is more abundant in October and November which represented the breeding season of this species.

Morphlogy: According to wright (1963a), Burch (1972) and Jawetz et al. (1987) the genus Bullnus possesses a sinistral shell and a pseudobranch; the head and foot regions are lighter in colour. It breathes by

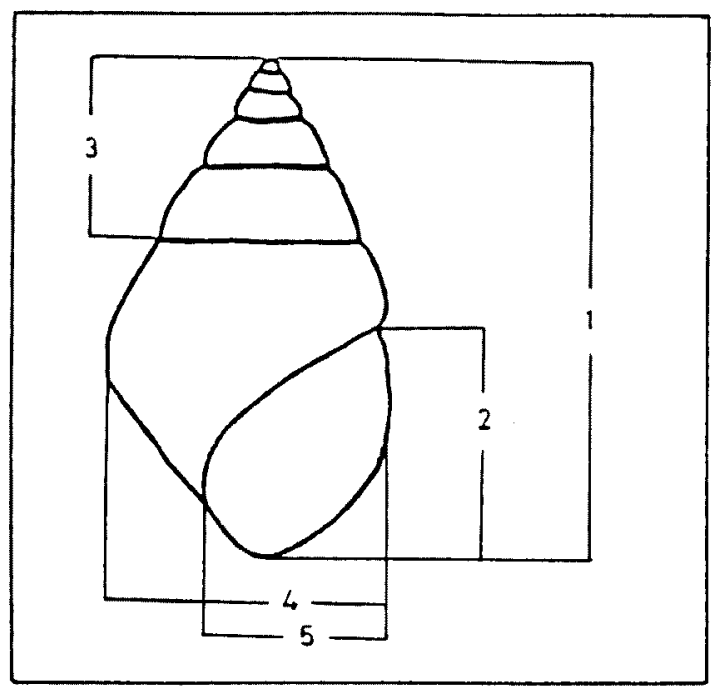

Fig. 1. Hypothetical model of a snail shell showing method of measuring various shell dimensions.

$\begin{array}{ll}\text { 1. Length. } 2 \text {. Aperture length. } & \end{array}$

3. Spiral height. 4. Width.

5. Aperture width.

a pulmonary sac and its shell is without an operculum. This species is hermaphrodite. The nervous system is composed of five ganglia which are: two pleural; two parietal and one abdominal.

The shell of this species is sinistral and narrowshaped, measuring from 9 to $16 \mathrm{~mm}$ in length and from 9 to $10 \mathrm{~mm}$ in width, i.e. $\mathrm{L} / \mathrm{W}$ ratio ranges from 1.3 to $1.6 \mathrm{~mm}$. It is rather thin and varies in colour from white to dark brown with apex pointed or blunt. The profile of the body whirls is evenly rounded. The shell aperture is wide-narrow, measuring about $1.3 \times 1.6 \mathrm{~mm}$. The shell of this species lacks an operculum and its spire ranges from short to medium. The (calcuated) mean $\mathrm{L} / \mathrm{AL}$ raito was $1.47 \mathrm{~mm}$ ranging from 1.4 to $1.6 \mathrm{~mm}$.

Cytogonetics: Fifty individuals of Bulinus truncatus species were collected from close-to bank river, irrigation canals and streams from different localities in Qena City. Somatic chromosomes of thirty five mitotic metaphase plates were analysed, then the chromosomes from the better ten spreads were cut out and arranged in pairs on the basis of size and centro- 


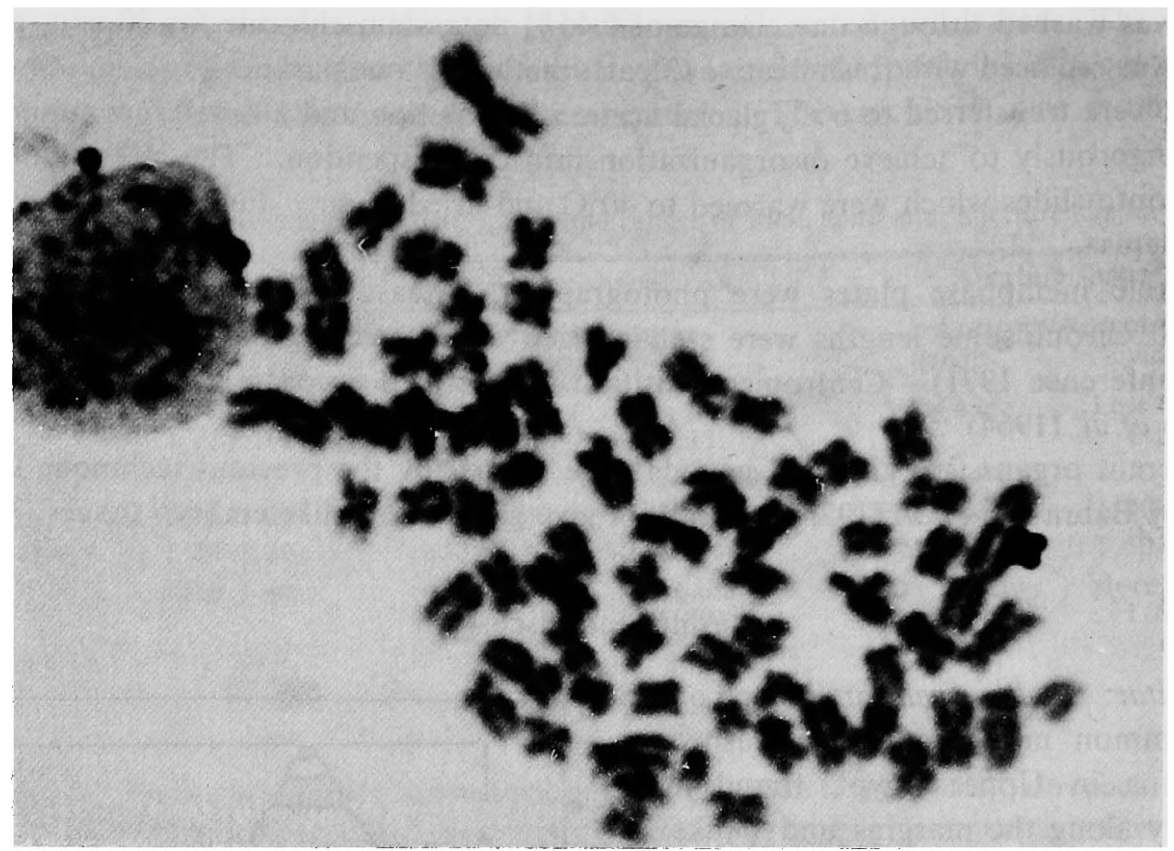

(a)
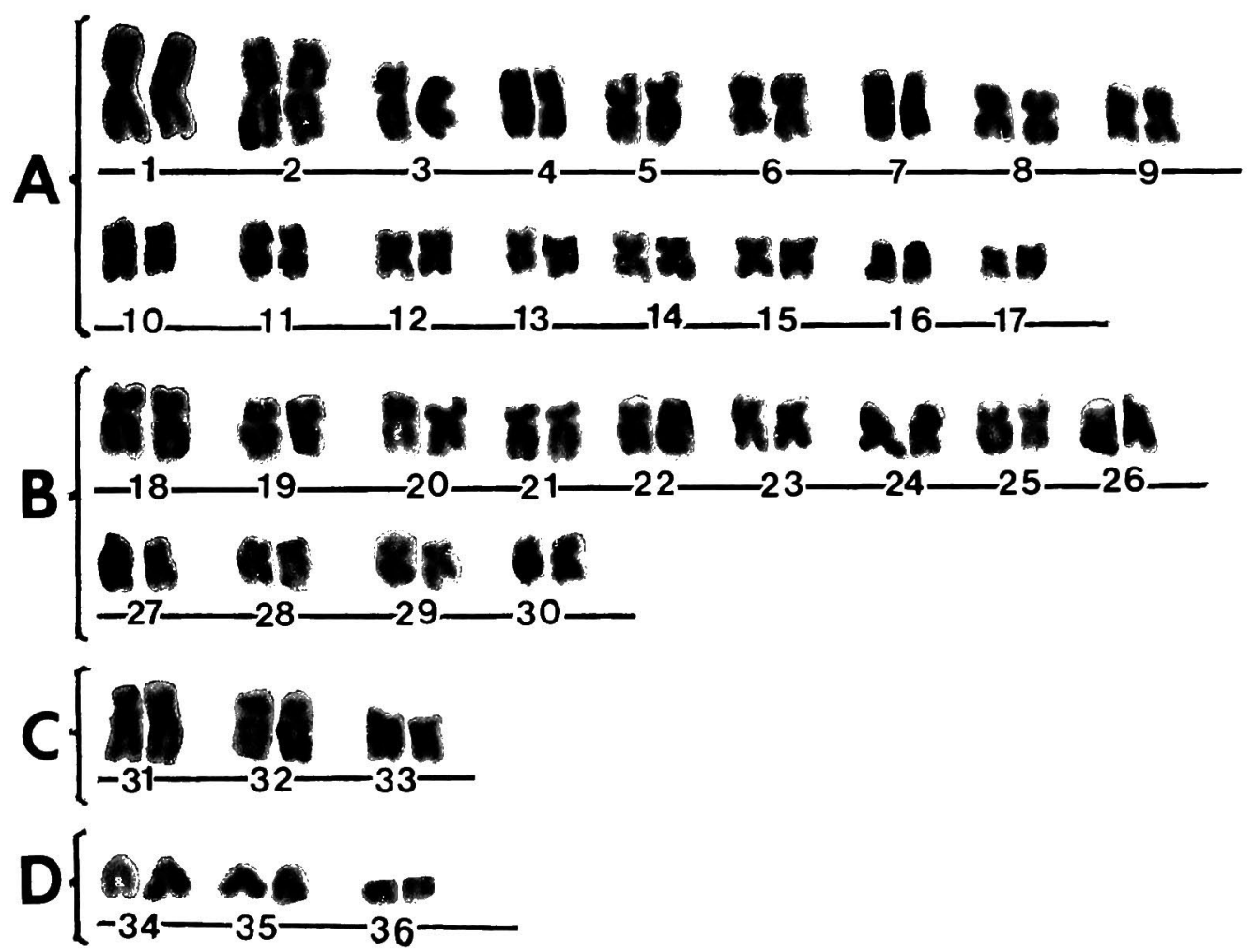

Fig. 2. A metaphase spread (a) and a karyotype (b) of the snail Bulinus truncatus $(2 n=72)$. 
meric position for the karyotypes. Slides prepared from embryo tissues showed a diploid chromosome number of 72 (Fig. 2). This result is in fair agreement with that reported by Burch (1964) and Brown and Burch (1967). Arm ratio, relative lengths and centromeric in-

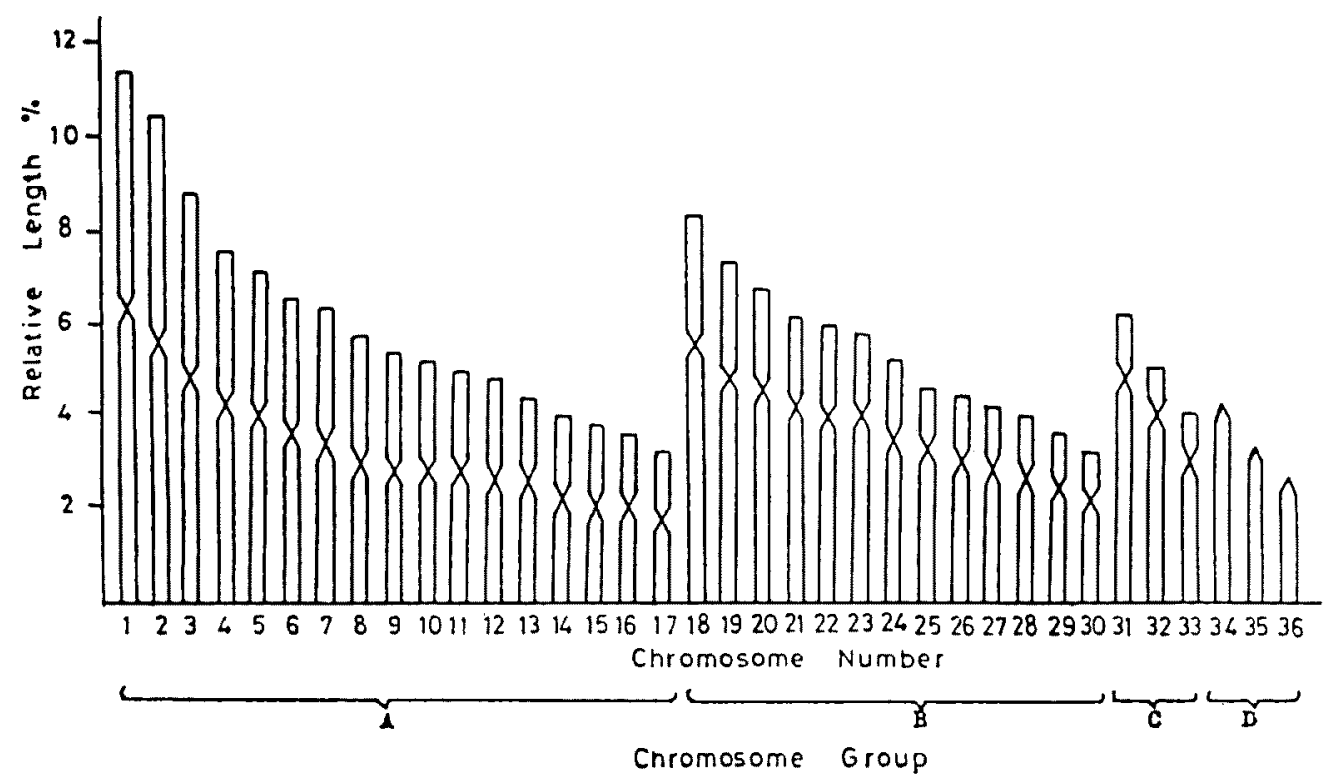

(I)

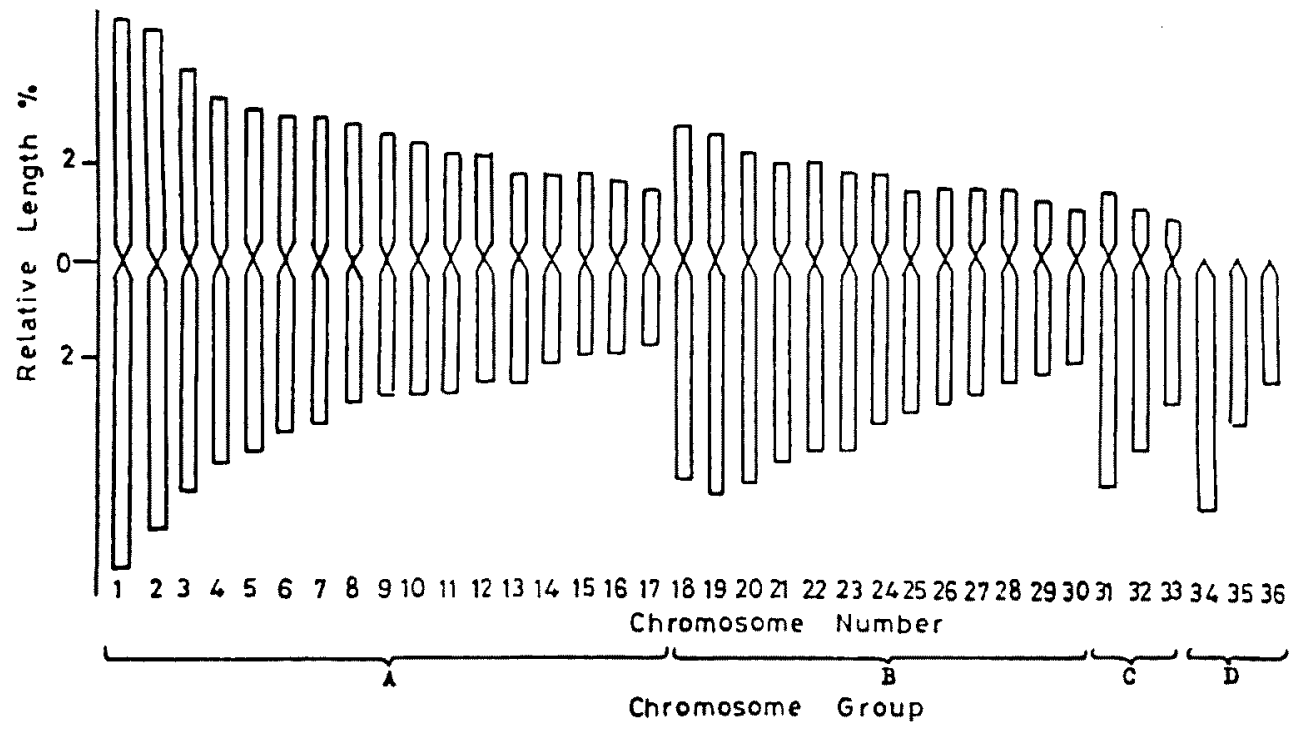

(II)

Fig. 3. Idiogram of the chromosomes of Bulinus truncatus Idiogram was constructed according to the relative length (I) and to the centromeric index (II).

dices are given in Table 3. Two idiograms (Fig. 3) were constructed based on either relative length or centromeric indices; for the latter centromeres were drawn at the same level making visual comparison easier. 


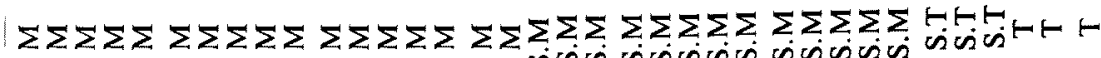

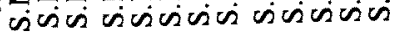

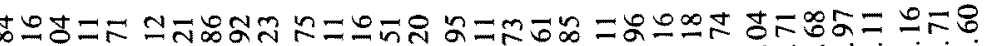

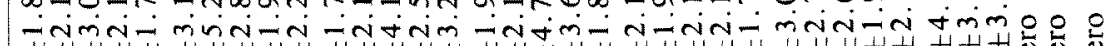

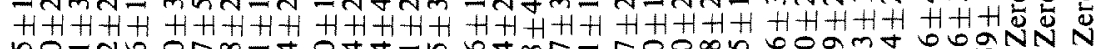

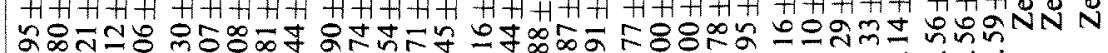

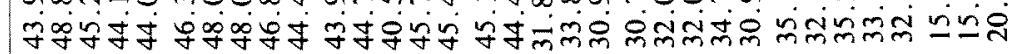

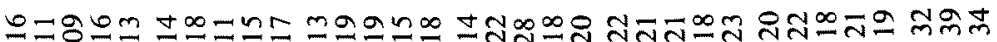
HOH H

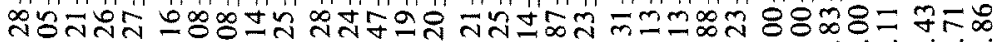

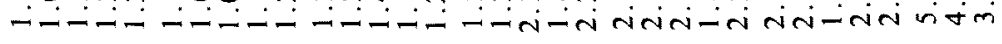

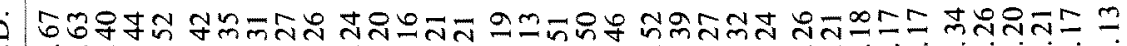

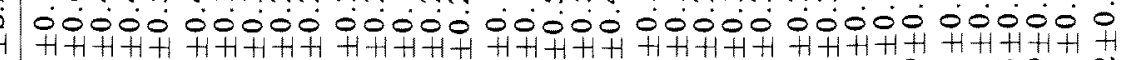

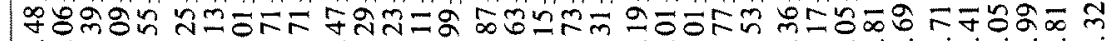

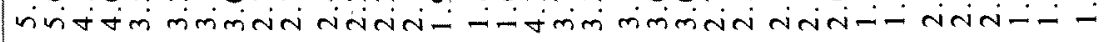

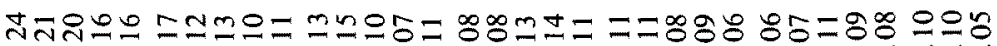

0000 000

$\mathrm{HH}+\mathrm{H}+\mathrm{H}+\mathrm{H}+\mathrm{H}+\mathrm{H}+\mathrm{H}+\mathrm{H}+\mathrm{H}+\mathrm{H}+\mathrm{H}+\mathrm{H}+\mathrm{H}+\mathrm{H}+\mathrm{H}+\mathrm{H}+\mathrm{H}+\mathrm{H}+\mathrm{H}$

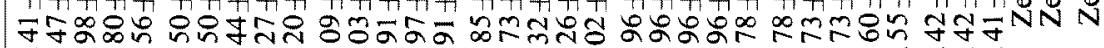

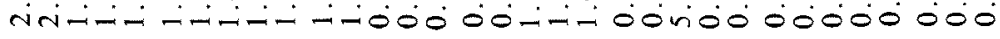

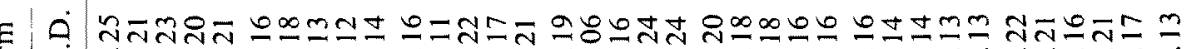
m $\dot{0} 0000$ 0000 an $H+H+H+H+H+H+H+H+H+H+H+H+H H+H+H+H+H+H+H+H+H$

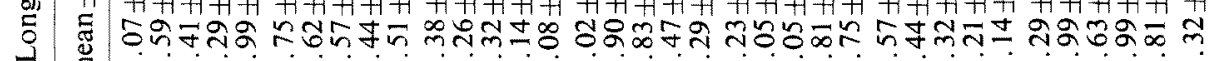

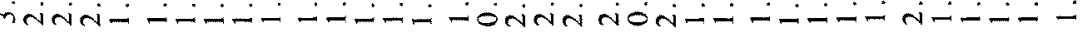

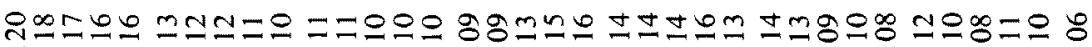
0000 00000 0000 0000000000000000

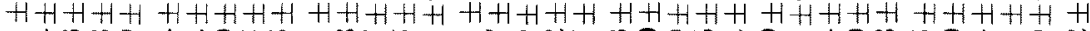

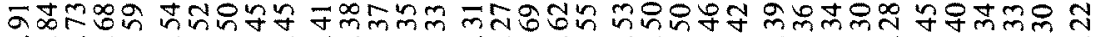
000000000000000000000000000000000000

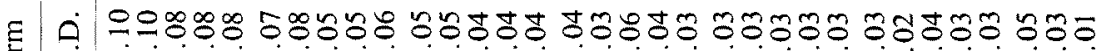

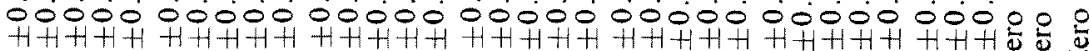

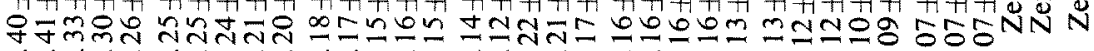
000000000000000000000000000000000

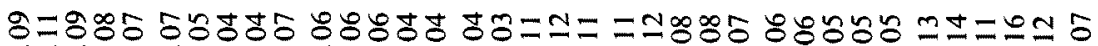
0000 00000 0000 0000 00000000000000 $H+H+H+H+H+H H+H+H+H+H+H H H+H+H+H+H+H+H+H H+H+H+H$

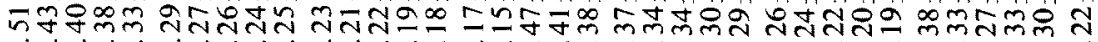
000000000000000000000000000000000000

它苍范 - 
Four groups of chrososomes were recognized according to the centromeric index length: Group A; seventeen metacentric pairs (Arm ratio 1.05-1.47), Group B; thirteen submetacentric pairs (Arm ratio 1.83-2.31); Group C; three subtelocentirc pairs (Arm ratio 3.86-5.43) and Group D; three telocentric pairs (Arm ratio).

Clougher (1971) reported that genus Bulinus has four different haploid chromosome numbers, i.e. $18,36,54$ and, 72 the first number being by far the most common number in some groups of Bulinus species (B. reticulatus, B. africanus and, B. forskali), while Bulinus truncatus (group) with a wide geographical distribution is obviously a tetraploid $(\mathrm{n}=36)$ or higher multiples $(n=54)$ and $(n=72)$ as shown in Table 2 .

The above mentioned description of the present study reveals that our results from the point of chromosome number agreed with the previous results, i.e. Bulinus truncatus in Egypt have haploid chromosome number of tetraploidy $(n=36)$ and the polyploidy series including diploid $(n=18)$, hexaploid $(n=54)$ and octaploid $(n=72)$ has been absent. This is also the first report of karyotypic details (Figs. 2, 3) of Bulinus truncatus (in Egypt).

\section{Summary}

Species of the qenus Bulinus occur as a polyploid series which is of interest because of the rarity of polyploidy in the animal kingdom and because it appears that there is some kind of relationship between polyploidy and the ability of this genus to transmit schistosomiasis, a parasitic disease of a major public health importance in most developing coutries. Chromosome analyses were performed in preparations of gonads, gills and embryos, from a hunded specimens of Bulinus truncatus which were collected from different localities around Qena City. The diploid chromosome number was determined to be seventy two $(2 n=72)$. The karyotype was made up of seventeen metacentric, thirteen submetacentric, three subtelocentric and three telocentric chromosome pairs. Considering previously reported cytogenetic data in the genus Bulinus, the present specimene appear to represent a tetraploid form and this is the first report in which detailed karyotype for Bulinus truncatus is presented. Habitat, morphological characters and shell measurements for this species are also described in detail in this paper.

\section{References}

Babrakzai, N., Miller, W. B. and Samsam, N. S. 1976. Procedures and methods in Molluscan cytology and cytogenetices. Bull. Amer. Malacol. Union. 57-61.

Brown, D. S. and Burch, J. B. 1967. Distribution of cytologically differet populations of the genus Bulinus (Basommatophora: Planorbidae) in Ethiopia. Ibid. 6: 189-198.

- 1978. Freshwater Molluscs. In: Biogeography and Ecology of Southern African (M. J. A. Werger ed.) pp. 1153-1180 Junk, The Hague.

Burch, J. B. 1964. Cytological studies of planorbidae (Basommatophora) the African subgenus Bulinus S. S Malacop. 1(3): 387-400.

- 1967. Chromosomes of intermediate hosts of human bilharziasis. Malacol. Int. J. Malacol. 5: 127-135

- 1972. Names for two polyploid species of African Bulinus (Basammatopora: Planorbidae). Malacol. Rev. 5: $1-8$.

- and Radke, M. G. 1971. Culturing Biomphalaria and Oncomelgnia (Gastropoda) for large scale studies of Schistosomiasis. part 1 Cultivation of Biomphalaira glabrata and maintenance of Schistosoma mansoni in the laboratory. (406 th Med. Lab., U. S. Army Med.) Dept. Activity. Japan.

Claugher, D. 1971. Karyotype analysis of Bulinid snails. Bull. W. H. O. 45: 855-858.

Goldman, M. A., Philip, T. 1., Chrisman, C. L. and Franklin, D. A 1984. Chromosomal evolution in planorbid snails of the genus Bulinus and Biomphalaria. Malacol. $25: 427-446$.

Gregorie, C. 1972. Structure of the molluscan shell. In Chemical Zoology (M. Florkin and B. T. Sckeer ed.) 3: 5-101. Academic press, New York. 
James, B. L. 1967. The characters and distribution of the subspecies and varieties of littorina saxaralis (Olivi) in Britain. Cah. Biol. Mar. 9: 143-165.

Jawetz, E., Melnick, J. L. and Adelberg, E. 1987. Review of Medical Microbiology. California Univ., San Francisco.

Levan, A., Fredga, K. and Sandberg, A. A. 1964. Nomenclature for centromeric position on chromosome. Hereditas 52: 201-220.

Natarajan, R. Burch, J. and Gismann, A. 1965. Cytological studies of planorbidae. 11 Some African planorbidae, Bulininae and planorbininae. Malacol. 1nt. J. Malacol., 2: 23-251.

Paris Conference, 1971. Standardizatioo in Human Cytogenetics. Birth Defects original Art. Ser. Vol. 8 No. 7. Wright, C. A. 1963. The freshwater gastropod molluses of Westen Aden Protectorate. Bull. Mus. Zool. 10: $257-274$.

- 1971. Bulinus of Aldabra and subfamily Bulininae In: The Indian Ocean areo-philosophical Transactions of the Ragol Society, London, B., 260: 299-313. 